\title{
THE PLASMA LIPID LEVEL IN PERIODONTAL HEALTH AND DISEASE- A CASE-CONTROL STUDY
}

\author{
Sregalatha Doraiswamy11, Vidya Albert Yen²
}

${ }^{1}$ Associate Professor, Department of Dental Surgery, Dharmapuri Medical College.

${ }^{2}$ Associate Professor, Department of Dental Surgery, Chengalpattu Medical College.

\section{ABSTRACT}

\section{BACKGROUND}

Periodontitis is a chronic inflammatory disease of the supporting structures of the teeth resulting from the dental plaque biofilm attached to the teeth. Recent studies have shown that oral disease may affect the systemic health. The aim of the present study was to estimate and compare fasting plasma lipids in case and control groups, and to establish its relationship with periodontitis.

\section{MATERIALS AND METHODS}

Sixty patients were selected within the age group of 40-50 years, which included both the sexes. Thirty patients with probing depth $\leq 3 \mathrm{~mm}$ were taken as Control group and thirty patients with probing depth $\geq 4 \mathrm{~mm}$ were taken as the Case group. \%mL of sample blood were collected 12 hours after fasting and sent for laboratory investigations for lipid profile. The data collected were statistically analysed.

\section{RESULTS}

In this present study, the mean total Cholesterol, triglycerides, LDL Cholesterol and VLDL Cholesterol levels were elevated in the Case group than the Control group and they were statistically significant. Although the mean HDL Cholesterol level was elevated in the Case group than the Control group it was not statistically significant.

\section{CONCLUSION}

The present study shows a significant relationship between periodontitis and hyperlipidaemia. The present study also supports the hypothesis that periodontal disease is a risk factor for cardiovascular disease.

\section{KEYWORDS}

Cholesterol, Risk Factor, Periodontitis.

HOW TO CITE THIS ARTICLE: Doraiswamy S, Yen VA. The plasma lipid level in periodontal health and disease- A case-control study. J. Evolution Med. Dent. Sci. 2017;6(48):3728-3730, DOI: 10.14260/Jemds/2017/804

\section{BACKGROUND \\ Periodontitis, a periodontal disease, results from interaction between the immune system and oral bacteria that may promote oxidative stress and initiate an inflammatory cascade inducing the destruction of oral structures.(1) The bacterial accumulation is predominantly Gram-negative resulting in an inflammatory response from the body. It has a potential in vascular dissemination of microorganisms \\ levels.(4) Several studies done by Losche et al, Katz et al have shown that there is a relationship between periodontitis and high serum lipid level.(4)Cutler et al concluded that plasma levels of lipids are significantly high in individuals with periodontitis than healthy subjects.(5) \\ Therefore, this study was performed to determine the relationship between chronic periodontitis and plasma lipid level.} through the sulcular epithelium and their products such as lipopolysaccharides (LPS) throughout the body.(2) Many studies have been done to show that the periodontal pathogens and inflammatory markers in the blood are correlated with increased risk of CVD.(3) Inflammatory biomarkers including high-sensitive C-reactive protein (CRP), fibrinogen, serum amyloid A, tumour necrosis factor $\alpha$ (TNF $\alpha$ ), interleukin-6 (IL-6)and cellular adhesion molecule are known CVD risk markers. ${ }^{(3)}$

Fentoglu et al reported that serum and gingival crevicular fluid levels of TNF- $\alpha$, IL-1 $\beta$ and IL- 6 seem to be relating factors between periodontal disease and high serum lipid

Financial or Other, Competing Interest: None.

Submission 01-05-2017, Peer Review 03-06-2017,

Acceptance 09-06-2017, Published 15-06-2017.

Corresponding Author:

Dr. Vidya Albert Yen,

3/2, East Road, West CIT Nagar,

Chennai-35.

E-mail: vidyaannie@yahoo.com

DOI: $10.14260 /$ jemds $/ 2017 / 804$

\section{MATERIALS AND METHODS}

This case-control study was conducted at Tamilnadu Government Dental College \& Hospital, Chennai. The study was approved by the ethical committee of the institution.

Sixty patients were selected from those attending the Periodontology Department of the hospital. The present study was done in December 2011 on patients with chronic periodontitis and compared with patients having normal periodontal health. Due to the short duration of the study and with only sixty patients consenting the sample was restricted to sixty and divided into two groups, one group with chronic periodontitis and the other group with normal periodontium. All patients were detailed about the study and informed consent was obtained.

The study group included patients with at least one periodontal pocket with depth more than $4 \mathrm{~mm}$ in every quadrant and radiographically showed bony destruction. The control group included patients who were periodontally healthy. That is these patients had probing depth less than 3 $\mathrm{mm}$ and there was no radiographic signs of destruction of bone. 
These patients were randomly selected from those attending the outpatient department of the Tamilnadu Government Dental \& Hospital. The intraoral examination was done with mouth mirror and William's graduated periodontal probe. The periodontal evaluation included Plaque index (Silness \& Loe 1964), gingival index (Loe \& Silness 1963) and full mouth probing depth and clinical attachment loss measurement. A thorough intraoral examination was done after obtaining the medical and dental history of the patients. These two groups were age and gender matched.

Both males and females in the age group of 40-50 who were systemically healthy according to their medical records were included in the study.

The exclusion criteria include individuals who had a history of any treatment done during the last 6 months, those with history of diabetes mellitus, endocrine disease, myocardial infarction, stroke, malignancy, history of smoking and those on medication for hyperlipidaemia.

The periodontal examination was done in a dental chair using a mouth mirror and William's graduated periodontal probe. Clinical oral examination included assessment of periodontal pockets in all teeth except the third molars.

All the subjects were referred to the hospital laboratory where fasting blood samples were collected to determine serum lipid levels using routine enzymatic colorimetric test. The pathological cut-off points according to laboratory recommendations were taken as: Total Cholesterol $>200$ $\mathrm{mg} / \mathrm{dL}, \mathrm{HDL}>55 \mathrm{mg} / \mathrm{dL}, \mathrm{LDL}>130 \mathrm{mg} / \mathrm{dL}$, VLDL >25-35 $\mathrm{mg} / \mathrm{dL}$, Triglycerides $>200 \mathrm{mg} / \mathrm{dL}$.

\section{Statistical Analysis}

The statistical analysis was done using SPSS version 15.0 software. Student's independent t-test and Chi-square test was used to compare difference in proportions.

Table I shows the mean standard deviation and test of significance of mean values between control and case group. Statistical analysis by student independent t-test shows the mean cholesterol level in the case group $(198 \pm 28.2)$ which is significantly higher than the control group. Similarly, the mean LDL level in the case group is $126.7 \pm 26$ which is also significantly higher in the case group than in the control group (98.2 \pm 19.3$)$.

The mean VLDL in the case group is $38 \pm 12.2$ which is also significantly higher than in the control group (23.3 \pm $10.3)$. The triglyceride levels in the case group $(191 \pm 61.9)$ is also higher than the control group (115 \pm 51$)$.

Table II shows the frequency of abnormal serum lipid levels in both groups. The proportion of abnormality of LDL, VLDL, Triglycerides in the study group is significantly higher than the control group.

\section{RESULTS}

Sixty patients were selected from those attending the Periodontology Department of Tamilnadu Government Dental College and Hospital.

The study group included patients with at least one periodontal pocket with depth more than $4 \mathrm{~mm}$ in every quadrant and showing bony destruction radiographically.

The control group included patients who were periodontally healthy, i.e. these patients had probing depth less than $3 \mathrm{~mm}$ and there were no radiographic signs of destruction of bone.

Table I shows the mean standard deviation and test of significance of mean values between control and case group. Statistical analysis by student independent t-test shows the mean cholesterol level in the case group $(198 \pm 28.2)$ which is significantly higher than the control group. Similarly, the mean LDL level in the case group is $126.7 \pm 26$ which is also significantly higher in the case group than in the control group $(98.2 \pm 19.3)$.

The mean VLDL in the case group is $38 \pm 12.2$ which is also significantly higher than in the control group $(23.3 \pm$ $10.3)$. The triglyceride levels in the case group $(191 \pm 61.9)$ is also higher than in the control group $(115 \pm 51)$.

Table II shows the frequency of abnormal serum lipid levels in both groups. The proportion of abnormality of LDL, VLDL, Triglycerides in the study group is significantly higher than the control group.

The bar graph shows the comparison of lipid profile in the control and the study groups. It is seen that the lipid levels are significantly higher in the patients with periodontitis than in patients with normal periodontium with the exception of HDL which is lower in the study group than the control group.

\begin{tabular}{|c|c|c|c|}
\hline Variables & $\begin{array}{c}\text { Control (n=30) } \\
\text { Mean } \pm \text { S.D. }\end{array}$ & $\begin{array}{c}\text { Study (n=30) } \\
\text { Mean } \pm \text { S.D. }\end{array}$ & $\begin{array}{c}\text { Student } \\
\text { t-test } \\
\text { p value }\end{array}$ \\
\hline Age & $42 \pm 3.4$ & $44.6 \pm 4.3$ & $0.13(\mathrm{NS})$ \\
\hline Cholesterol & $161 \pm 21.7$ & $198.6 \pm 28.2$ & $0.002(\mathrm{Sig})$ \\
\hline $\begin{array}{c}\text { HDL } \\
\text { Cholesterol }\end{array}$ & $36.3 \pm 5.9$ & $35.1 \pm 7.7$ & $0.68(\mathrm{NS})$ \\
\hline $\begin{array}{c}\text { LDL } \\
\text { Cholesterol }\end{array}$ & $98.2 \pm 19.3$ & $126.7 \pm 26.7$ & 0.007 (Sig) \\
\hline $\begin{array}{c}\text { VLDL } \\
\text { Cholesterol }\end{array}$ & $23.3 \pm 10.3$ & $38.0 \pm 12.2$ & $0.004(\mathrm{Sig})$ \\
\hline Triglycerides & $115.5 \pm 51.0$ & $191.1 \pm 61.9$ & $0.003(\mathrm{Sig})$ \\
\hline Table
\end{tabular}

Table I. Mean, Standard Deviation and Test of Significance of Mean Values between Control and Study Groups

\begin{tabular}{|c|c|c|c|}
\hline \multirow{2}{*}{ Variables } & $\begin{array}{c}\text { Control } \\
\text { (n=30) }\end{array}$ & $\begin{array}{c}\text { Study } \\
\text { (n=30) }\end{array}$ & \multirow{2}{*}{ P-value* } \\
\cline { 2 - 3 } & $\begin{array}{c}\text { No. of } \\
\text { Patient \% }\end{array}$ & $\begin{array}{c}\text { No. of } \\
\text { Patients \% }\end{array}$ & \\
\hline $\begin{array}{c}\text { Total Cholesterol } \\
\text { Abnormal }\end{array}$ & $4(13 \%)$ & $21(70 \%)$ & $\begin{array}{c}0.001 \\
(\mathrm{Sig}) \#\end{array}$ \\
\hline $\begin{array}{c}\text { HDL } \\
\text { Abnormal }\end{array}$ & $13(41.7 \%)$ & $18(60 \%)$ & $0.68(\mathrm{NS})$ \\
\hline $\begin{array}{c}\text { LDL } \\
\text { Abnormal }\end{array}$ & $1(3 \%)$ & $22(75 \%)$ & $0.004(\mathrm{Sig})$ \\
\hline $\begin{array}{c}\text { VLDL } \\
\text { Abnormal }\end{array}$ & $5(16.7 \%)$ & $20(66.7 \%)$ & $0.04(\mathrm{Sig})$ \\
\hline $\begin{array}{c}\text { Triglycerides } \\
\text { Abnormal }\end{array}$ & $5(16.7 \%)$ & $20(66.7 \%)$ & $0.04(\mathrm{Sig})$ \\
\hline \multicolumn{3}{|c|}{ Table II. Comparison of Proportion of Abnormality } \\
between Control and Study Groups
\end{tabular}

*Chi-square test with Yates correction was used to calculate p-values.

\# Fisher's exact test (2-tailed) was used to calculate pvalue. 


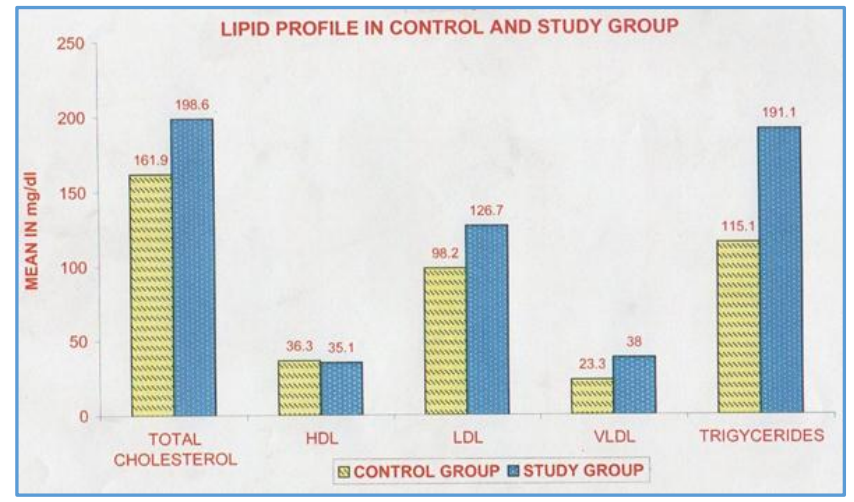

\section{DISCUSSION}

In this present study, all the parameters in the lipid profile were significantly higher in the patients with periodontal disease than of those who were normal.

Periodontal disease is an infectious disease caused by Gram-negative anaerobic bacteria. It has been shown that acute infections can interrupt lipid metabolism and there is a significant rise in plasma triglycerides during Gram-negative bacterial infections.(6) Cytokines such as TNF- $\alpha$, IL-1 $\beta$ are known to play a possible role in the development and progression of atherosclerotic diseases.(7) These cytokines increase the mobilisation of lipids from the liver and adipose tissue $^{(8)}$ and increase the binding of LDL to endothelium and smooth muscles.(9) The oxidative modification of LDL leads to an increase in cholesterol accumulation because modified LDL is very susceptible to macrophage uptake. Studies have also shown that progressive periodontitis also leads to hyperlipidaemia.(10)

Studies conducted by Katz(11) and Cutler(5) have shown a correlation between deep periodontal pockets and high Cholesterol and LDL levels in men but not in women. In their studies, the women were in fertility age, the inhibitory effect of oestrogen on lipid metabolism led to low levels of LDL \& cholesterol.(12) But in this present study, the age group selected for both the groups was 40-50 years. Other confounding factors related to elevated Cholesterol levels like smoking and blood pressure were eliminated in this study like those done by Cutler et al,(5) Loesche et al.(13) Subjects with BMI $\geq 30$ were excluded in the present study because many studies have shown a relationship between obesity and periodontal disease.(14)

Beck et al(15) in their study suggested that periodontal disease and atherosclerosis have common genetic predisposition i.e. hyper-inflammatory monocyte phenotype trait. Hence, patients with family history of periodontal disease and atherosclerosis were excluded in the present study. Noack et al stated that the relationship between hyperlipidaemia and periodontal disease could be due to polymorphonuclear leucocytes dysfunction. ${ }^{(4)}$

\section{CONCLUSION}

The results of the present study show a significant relationship between periodontitis and hyperlipidaemia, but further studies with larger population need to be done to confirm this relationship. The present study also supports the hypothesis that periodontal disease is a risk indicator of cardiovascular disease.

\section{REFERENCES}

[1] Sculley DV. Periodontal disease modulation of the inflammatory cascade by dietary n-3 polysaturated fatty acids. J Periodontol Res 2014;49(3):277-81.

[2] Mealy BL, Klokkevold PR. Periodontal medicine. Carranza's clinical periodontology. $9^{\text {th }}$ edn. New Delhi: Elsevier 2004:229-44.

[3] Bokhari SAH, Khan AA, Leung WK. et al. Association of periodontal and cardiovascular diseases: South-Asian studies 2001-2012. Journal of Indian Society of Periodontology 2015;19(5):495-500.

[4] Hagh LG, Zakavi F, Hajizadeh F, et al. The Association between Hyperlipidemia and Periodontal Infection. Iranian Red Crescent Medicinal Journal 2014;16(2): e6577.

[5] Cutler CW, Shinedling EA, Nunn M, et al. Association between periodontitis and hyperlipidemia: cause or effect? J Periodontol 1999;70(12):1429-34.

[6] Warner C, Zimmermann J, Quaschning T, et al. Inflammation, dyslipidemia and vascular risk factors in hemodialysis patients. Kidney Int Suppl 1997;62: S53-5.

[7] Kinane DF. 'Periodontal diseases' contributions to cardiovascular disease: an overview of potential mechanisms. Ann Periodontal 1998;3(1):142-50.

[8] Iacopino AM, Cutler CW. Pathophysiological relationships between periodontitis and systemic diseases: recent concepts involving serum lipids. J Periodontol 2000;71(8);1375-84.

[9] Hajjar DP, Habeland ME. Lipoprotein trafficking in vascular cells. Molecular Trojan horses and cellular saboteurs. J Biol Chem 1997;272(37):22975-8.

[10] Piotrowski JJ, Hunter GC, Eskelson CD, et al. Evidence for lipid peroxidation in atherosclerosis. Life Sci 1990;46(10):715-21.

[11] Katz J, Fugelmann MY, Goldberg A, et al. Association between periodontal pocket and elevated Cholesterol and low density lipoprotein Cholesterol levels. J Periodontol 2002;73(5):494-500.

[12] Herrington DM, Reboussin DM, Brosnihan KB, et al. Effects of oestrogen replacement on the progression of coronary-artery atherosclerosis. N Eng J Med 2000;343(8):522-9.

[13] Losche W, Karapetow F, Pohl A, et al. Plasma lipid and blood glucose levels in patients with destructive periodontal disease. JCP 2000;27(8):537-41.

[14] Saito T, Shimazaki Y, Koga T, et al. Relationship between upper body obesity and periodontitis. J Dent Res 2001;80(7):1631-6.

[15] Beck J, Garcia R, Heiss G. Periodontal disease and cardiovascular disease. J Periodontal 1996;67(Suppl 10):1123-37. 